\title{
Temporal distribution of ichthyoplankton near Beaufort Inlet, North Carolina
}

\author{
William F. Hettler Jr, Alexander J. Chester \\ National Marine Fisheries Service, Southeast Fisheries Center, Beaufort Laboratory, Beaufort, North Carolina 28516, USA
}

\begin{abstract}
Temporal distribution of the larval/early juvenile fish community of a major inlet on the North Carolina coast was studied from August 1986 through July 1987 using bow-mounted pushnets. Three main seasonal assemblages were observed: winter/early spring, late spring, and summer. Peak abundance occurred in late spring; few fishes were caught in November. Cold-water $\left(<20^{\circ} \mathrm{C}\right)$ species were primarily late post-flexion and transforming larvae, whereas many of the warm-water species were pre-flexion or flexion stage larvae (indicating near-by, possibly estuarine, spawning). Families with the most species were Bothidae, Gobiidae, and Sciaenidae. A total of 74 species or species groups were collected. Engraulidae made up $70 \%$ of the total catch out of the 34 families collected. High variability was noted between samples within collections. One-third of the species collected were found to invade adjacent saltmarsh habitat as juveniles.
\end{abstract}

\section{INTRODUCTION}

Inlets provide a convenient location to measure the time of first appearance, duration of occurrence and relative densities of estuarine-dependent species as they disperse from offshore spawning grounds to their estuarine nursery grounds. Improvements in sampling techniques for early life history stages in inlets may allow flux estimates and, ultimately, an understanding of the variability in interannual abundance for species of concern. By coupling flux rates with growth rate and age estimates using otolith analysis, cohorts may be tracked into their estuarine life history phase to identify sources of recruitment variability.

The distribution and abundance of larvae of several commercially valuable species of Sciaenidae, Clupeidae and Bothidae occurring along the coast and in the estuaries of North Carolina, USA, has been studied (see citations below), but the relative abundance and time of occurrence of the early life history stages of many other species is unknown in these waters. Studies on the fish larvae occurring near Beaufort Inlet, North Carolina, began in the late 1920's (Hildebrand \& Cable 1930, 1938). Subsequent ichthyoplankton surveys in this location concentrated on the fall and winter spawning species Atlantic menhaden Brevoortia tyrannus, Atlantic croaker Micropogonias undulatus, spot Leiostomus xanthurus, southern flounder Paralichthys lethostigma, and summer flounder $P$. dentatus (Tagatz \& Dudley 1961, Lewis \& Mann 1971, Lewis \& Wilkens 1971, Thayer et al. 1974, Weinstein et .al..1980, Judy 1982, Warlen 1982, Lewis \& Judy 1983, Thayer et al. 1983, Warlen \& Chester 1985, Warlen \& Burke 1990). For most other species found in the estuaries and inshore coastal waters of North Carolina (e.g. the Engraulidae and Gobiidae), when and where their larvae occur is not well known. Year-round sampling of the fish larvae of the Cape Fear River estuary, $120 \mathrm{~km}$ southwest of Beaufort, has been conducted since 1977 (CP \& L 1989), but these reports are limited to only a few (about 10) of the major species and are not published.

This paper describes the seasonal abundance of ichthyoplankton at Beaufort Inlet sampled throughout an entire year. It presents estimates of the numbers, kinds and sizes of fish larvae and early juveniles in the inlet during an annual cycle, groups the species into temporal assemblages, describes their relationship with temperature and lunar phase, notes the variability observed in fish densities within collections, and compares the observed larval fish species composition of the collections with the fish species reported to use adjacent saltmarsh habitat during the same sampling period (Hettler 1989). 


\section{STUDY AREA AND METHODS}

Ichthyoplankton were sampled approximately every 2 wk from August 1986 through July 1987, at times of new and full moon spring tides. All sampling occurred at night during the last $2 \mathrm{~h}$ of flood tide. Collections were made only at night because day densities of ichthyoplankton may represent a small percentage of the night densities (Olney \& Boehlert 1988) due to increased occupation of the upper water column and/or decreased net avoidance at night. The last of the flood tide was fished to minimize catching ichthyoplankton entrained in estuarine waters during previous tidal exchanges. The station was located in an inlet tidal pass, Bulkhead Channel, ca $1 \mathrm{~km}$ inside of Beaufort Inlet ( $\left.34^{\circ} 42^{\prime} \mathrm{N}, 76^{\circ} 40^{\prime} \mathrm{W}\right)$. Station depth averaged $6 \mathrm{~m}$ over the $300 \mathrm{~m}$ long sampling transect, which was oriented parallel with the axis of the $300 \mathrm{~m}$ wide channel. Salinity, temperature, and wind speed and direction at times of collections are shown in Fig. 1. The $15 \mathrm{yr}$ average (1974 to 1989 ) water temperature monitored near the station is provided on the figure for comparison.

Fishes were collected with a dual pushnet mounted on the bow of a $6.7 \mathrm{~m}$ outboard motor boat (Fig. 2). The pushnet, adapted from descriptions of other surface samplers (e.g. Hodson et al. 1981), has a number of advantages over towed nets. There is no preceding bridle and tow line to disturb the water column in front of the net. The net mouth fishes in front of the boat's wake. The fixed net length and operating position prevents the cod-end of the net from contacting the outboard motor propeller. Boat steerage in either direction is unaffected with nets deployed. The nets can be operated by one person in addition to the driver. Less than a minute is needed to deploy or retrieve both nets. The cod end collecting cups can be retrieved, emptied and reattached to the net with the boat underway and the nets deployed if continuous samples along a transect are needed. The gear can be fished actively, as in this study, or passively while anchored in a tidal channel.

The pushnet, constructed of aluminum tubing and flat bar, consisted of a pair of circular net frames that pivoted down for fishing and up for washing the collection out of each net. Each nylon net was $1 \mathrm{~m}$ in diameter, $5 \mathrm{~m}$ long, with a straight conical taper from mouth to cod-end. The port-side net was $0.5 \mathrm{~mm}$ mesh ( $49 \%$ open area) and starboard-side net was $0.8 \mathrm{~mm}$ mesh (55\% open area). A flowmeter (General Oceanics model 2030R) was mounted inside the mouth of each net to measure water volumes filtered.

When fishing, the nets sampled the top meter of water. Sampling speed was maintained at $1.4 \mathrm{~m} \mathrm{~s}^{-1}$ through the water (monitored with a Marsh-McBirney model 201 current meter). Sampling tows were always

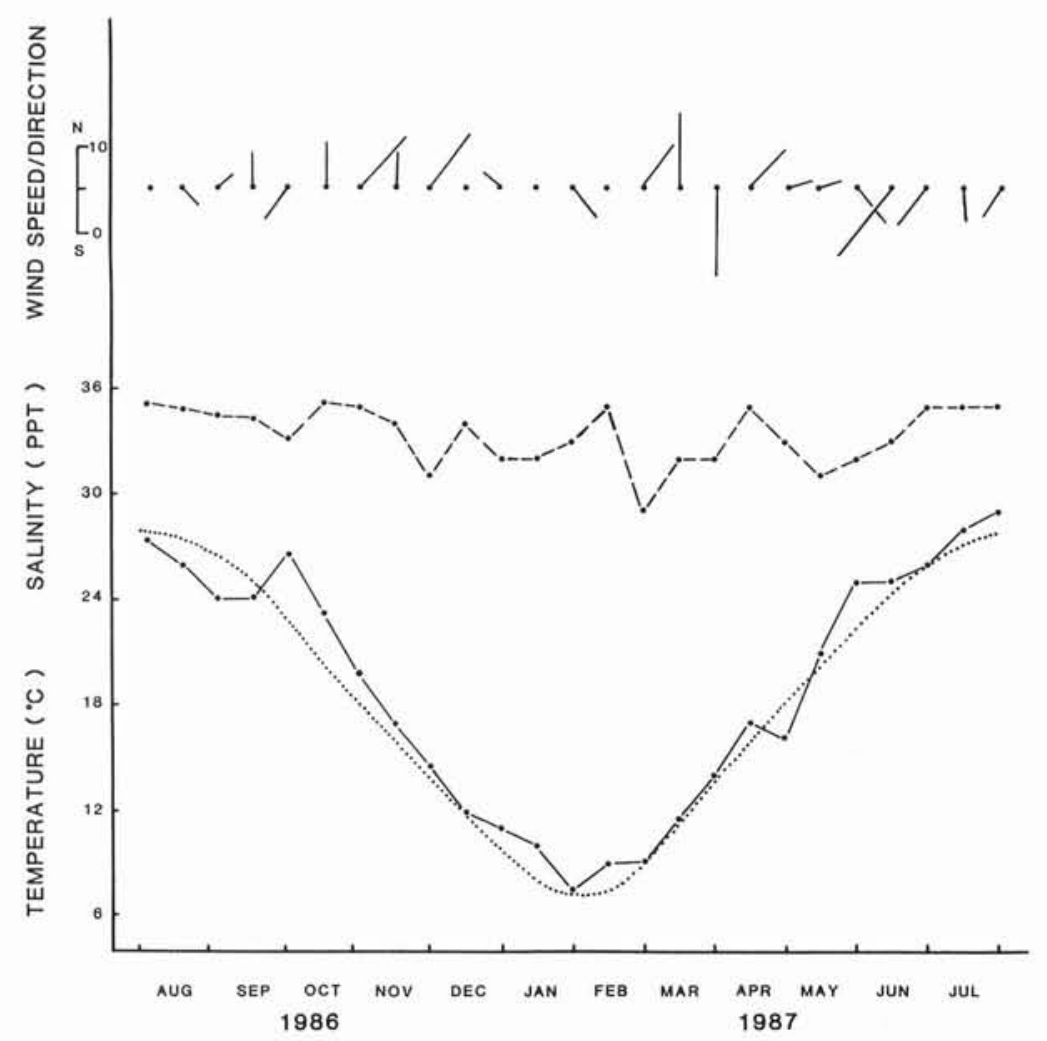

Fig. 1. Station temperatures (solid line) and salinities (dashed line) at times of the 25 collections. Dotted line is $15-\mathrm{yr}$ average seawater temperature $1 \mathrm{~km}$ from station. Windspeed (m $\mathrm{s}^{-1}$ ) and direction wind came from is indicated on top axis by collection 
Fig. 2. Fishing position of the $1 \mathrm{~m}$ diameter, $5 \mathrm{~m}$ long pushnets. Frames rotated independently upward when not fishing

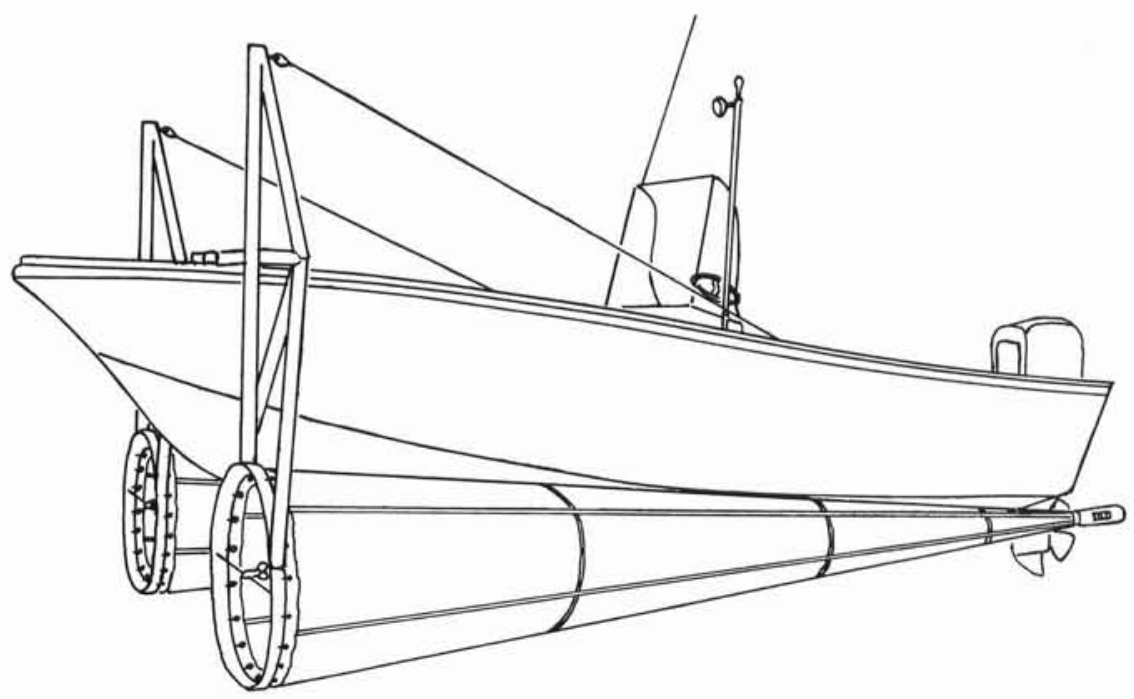

made into the flow of the incoming tide. Sampling time for each of the 6 paired hauls on each collection night was $3 \mathrm{~min}$. Elapsed time between consecutive hauls was ca $20 \mathrm{~min}$. Ichthyoplankton collections were washed from the nets and preserved in $10 \%$ formalin/ seawater.

In the laboratory, fish were removed, identified and counted. Up to 20 fish of each species from each mesh size of each collection were measured to the nearest $\mathrm{mm}$ (standard length) as they were encountered along a motor-driven sorting tray (unpubl.) in which the specimens were randomly dispersed. The $15 \times 30 \mathrm{~cm}$ tray, partitioned into $1-\mathrm{cm}$-wide channels which pass through the optical field of a dissecting microscope at the rate of $50 \mathrm{~cm} \mathrm{~min}^{-1}$, was started or stopped with a foot switch by the sorter, freeing the hands to pick out specimens and tally numbers of each species. Species representatives were retained as voucher specimens from each collection.

Species-specific catch information from each net was converted to density (numbers per $100 \mathrm{~m}^{3}$ ) and averaged for each collection date. The resulting data were compiled in a species-by-collection matrix and then were analyzed for temporal trends in the composition of the ichthyoplankton community. Species were divided into 2 groups: those found during at least 5 of the 25 collections and those found in 4 or less collections. Only data from the $0.5 \mathrm{~mm}$ net were included.

We summarized species and collection relationships with correspondence analysis (reciprocal averaging) (Greenacre 1984, Pielou 1984). Correspondence analysis considers a matrix of species abundance as a chisquare contingency table and arranges (ordinates) species and collections along a reduced number of axes, each representative, ideally, of an ecologically meaningful gradient. The technique resembles principal component analysis, but differs in that abundances are weighted by collection and species totals, and chisquare, rather than Euclidean, distances are used. Correspondence analysis appears to be superior to principal component analysis in the analysis of community data because higher axis distortions (the so-called arch effect) are reduced and because it is less sensitive to departures from linearity (Gauch et al. 1981, Gauch 1982).

\section{RESULTS}

Seventy-four fish species or genera representing 34 families were collected during the study (Table 1). Families with the most species included Bothidae, Gobiidae, and Sciaenidae. A total of 102460 fish were collected from the 3003 -min tows with both nets. The mean water volume sampled per sample was $196.2 \pm 0.59 \mathrm{SE} \mathrm{m}^{3}$.

Thirty-four of the 66 species caught during the year with the $0.5 \mathrm{~mm}$ mesh net occurred in 5 or more collections (Fig. 3). Peak densities of 'cold-water' $\left(<20^{\circ} \mathrm{C}\right)$ species occurred from late January to late March, whereas peak densities for the majority of the 'warmwater' $\left(>20^{\circ} \mathrm{C}\right)$ species occurred between late May and early June. Thirty-two other species occurred in 4 or less collections during the year (Fig. 4), which may reflect for some species (i.e. sciaenids) a strong pulse in recruitment (during late spring) possibly related to a very short spawning period.

The number of species caught in the $0.5 \mathrm{~mm}$ mesh net during the year ranged from 3 in mid-November to 32 in late May. Mean fish densities were 3 orders of magnitude greater in late May than they were in November (Fig. 5), due primarily to Anchoa larvae. This species group had a mean density of 4250 larvae per $100 \mathrm{~m}^{3}$ in both nets and constituted $85 \%$ of the total catch. 
Table 1. Species code, list of species, common name and total number of each of the 74 species caught in both nets from August 1986 through July 1987 , at Beaufort Inlet. ' Species caught only in the $0.8 \mathrm{~mm}$ mesh net

\begin{tabular}{|c|c|c|c|}
\hline Code & Species & Common name & Total number \\
\hline ABSA & - Abedefduí saxatilis & Sergeant major & 1 \\
\hline ALSC & Aluterus schoepfi & Orange filefish & 17 \\
\hline ANHE & Anchoa hepsetus & Striped anchovy & 4859 \\
\hline ANMI & Anchoa mitchilli & Bay anchovy & 265 \\
\hline ANRO & Anguilla rostrata & American eel & 26 \\
\hline ANSP & Anchoa spp. & Anchovy & 71375 \\
\hline ARPR & - Archosargus probatocephalus & Sheepshead & 9 \\
\hline ASGU & Astroscopus guttatus & Northern stargazer & 1 \\
\hline $\mathrm{BACH}$ & Bairdiella chrysoura & Silver perch & 6228 \\
\hline BRTY & Brevoortia tyrannus & Atlantic menhaden & 1637 \\
\hline CEST & Centropristis striata & Black sea bass & 7 \\
\hline $\mathrm{CHBO}$ & Chasmodes bosquianus & Striped blenny & 52 \\
\hline CHSC & Chilomycterus schopefi & Striped burrfish & 1 \\
\hline CISP & Citharichthys spp. & Flounder & 99 \\
\hline COOC & Conger oceanicus & Conger eel & 46 \\
\hline CYNE & Cynoscion nebulosus & Spotted seatrout & 119 \\
\hline CYRE & Cynoscion regalis & Weakfish & 3140 \\
\hline DASP & - Dactyloscopus spp. & Stargazer & 1 \\
\hline DEPU & Decapterus punctatus & Round scad & 76 \\
\hline DOMA & Dormitator maculatus & Fat sleeper & 2 \\
\hline ELSA & Elops saurus & Lady fish & 14 \\
\hline ETCR & Etropus crossotus & Fringed flounder & 28 \\
\hline ETMI & Etropus microstomus & Smallmouth flounder & 24 \\
\hline ETSP & Etropus spp. & Flounder & 6 \\
\hline EUSP & Eucinostomus spp. & Mojarra & 20 \\
\hline GOBO & Gobionellus boleosoma & Darter goby & 425 \\
\hline GOBS & Gobiosoma bosci & Naked goby & 81 \\
\hline GOGI & Gobiosoma ginsburgi & Seaboard goby & 145 \\
\hline GOHA & Gobionellus hastatus & Sharptail goby & 27 \\
\hline GOSP & Gobiosoma spp. & Goby & 1202 \\
\hline GOST & Gobiesox strumosus & Skilletfish & 5 \\
\hline HIER & Hippocampus erectus & Lined seahorse & 59 \\
\hline HYHE & Hypsoblennius hentzi & Feather blenny & 288 \\
\hline HYUN & $\cdot$ Hyporhamphus unifasciatus & Halfbeak & 1 \\
\hline LARH & Lagodon rhomboides & Pinfish & 365 \\
\hline LEXA & Leiostomus xanthurus & Spot & 2013 \\
\hline MEAT & Megalops atlanticus & Tarpon & 4 \\
\hline MEME & Menidia menidia & Atlantic silverside & 23 \\
\hline MESP & Menticirrhus spp. & Kingfish & 198 \\
\hline MIGU & Microgobius gulosus & Clown goby & 312 \\
\hline MIUN & Micropogonias undulatus & Atlantic croaker & 2305 \\
\hline MOHI & Monacanthus hispidus & Planehead filefish & 28 \\
\hline MUCE & Mugil cephalus & Striped mullet & 140 \\
\hline MUCU & Mugil curema & White mullet & 4 \\
\hline MYMI & Mycteroperca microlepis & Gag & 5 \\
\hline MYPU & Myrophis punctatus & Speckled worm eel & 1337 \\
\hline OPCR & Ophichthus cruentifer & Margined snake eel & 2 \\
\hline OPGO & - Ophichthus gomesi & Snake eel & 16 \\
\hline OPOG & Opistonema oglinum & Atlantic thread herring & 459 \\
\hline OPSP & Ophidion spp. & Cusk eel & 1 \\
\hline $\mathrm{ORCH}$ & Orthopristis chrysoptera & Pigfish & 1924 \\
\hline PAAL & Paralichthys albigutta & Gulf flounder & 486 \\
\hline PADE & Paralichthys dentatus & Summer flounder & 795 \\
\hline PALE & Paralichthys lethostigma & Southern flounder & 16 \\
\hline PEAL & - Peprilus alepidotus & Harvestfish & 3 \\
\hline PETR & Peprilus triacanthus & Butterfish & 19 \\
\hline $\mathrm{POCH}$ & Pogonias chromis & Black drum & 4 \\
\hline POSA & Pomatomus saltatrix & Blue fish & 10 \\
\hline PRSP & Prionotus spp. & Searobin & 311 \\
\hline SAAU & Sardinella aurita & Spanish sardine & 233 \\
\hline
\end{tabular}


Table 1 (continued)

\begin{tabular}{|c|c|c|c|}
\hline Code & Species & Common name & Total number \\
\hline SCAQ & Scopthalmus aquosus & Windowpane & 11 \\
\hline SCMA & Scomberomorus maculatus & Spanish mackerel & 96 \\
\hline SCOC & Sciaenops ocellatus & Red drum & 3 \\
\hline SPBO & Sphyraena borealis & Northern sennet & 2 \\
\hline SPMA & Sphoeroides maculatus & Northern puffer & 37 \\
\hline SYCI & Symphurus civitatus & Offshore tonguefish & 14 \\
\hline SYFL & Syngnathus floridae & Dusky pipefish & 5 \\
\hline SYFO & Synodus foetens & Inshore lizardfish & 26 \\
\hline SYFU & Syngnathus fuscus & Northern pipefish & 48 \\
\hline SYLO & Syngnathus louisianae & Chain pipefish & 428 \\
\hline SYPL & Symphurus plagiusa & Blackcheek tonguefish & 343 \\
\hline TRFA & - Trachinotus falcatus & Permit & 2 \\
\hline TRMA & Trinectes maculatus & Hogchoker & 138 \\
\hline URRE & Urophycis regia & Spotted hake & 7 \\
\hline
\end{tabular}

Fig. 3. Date of capture and approximate density of 34 species caught in 5 or more collections with the $0.5 \mathrm{~mm}$ net. Arranged vertically by time of peak density (as indicated by vertical line). See Table 1 for species code. Each increase in size of the closed circles represents one order of magnitude increase in relative density

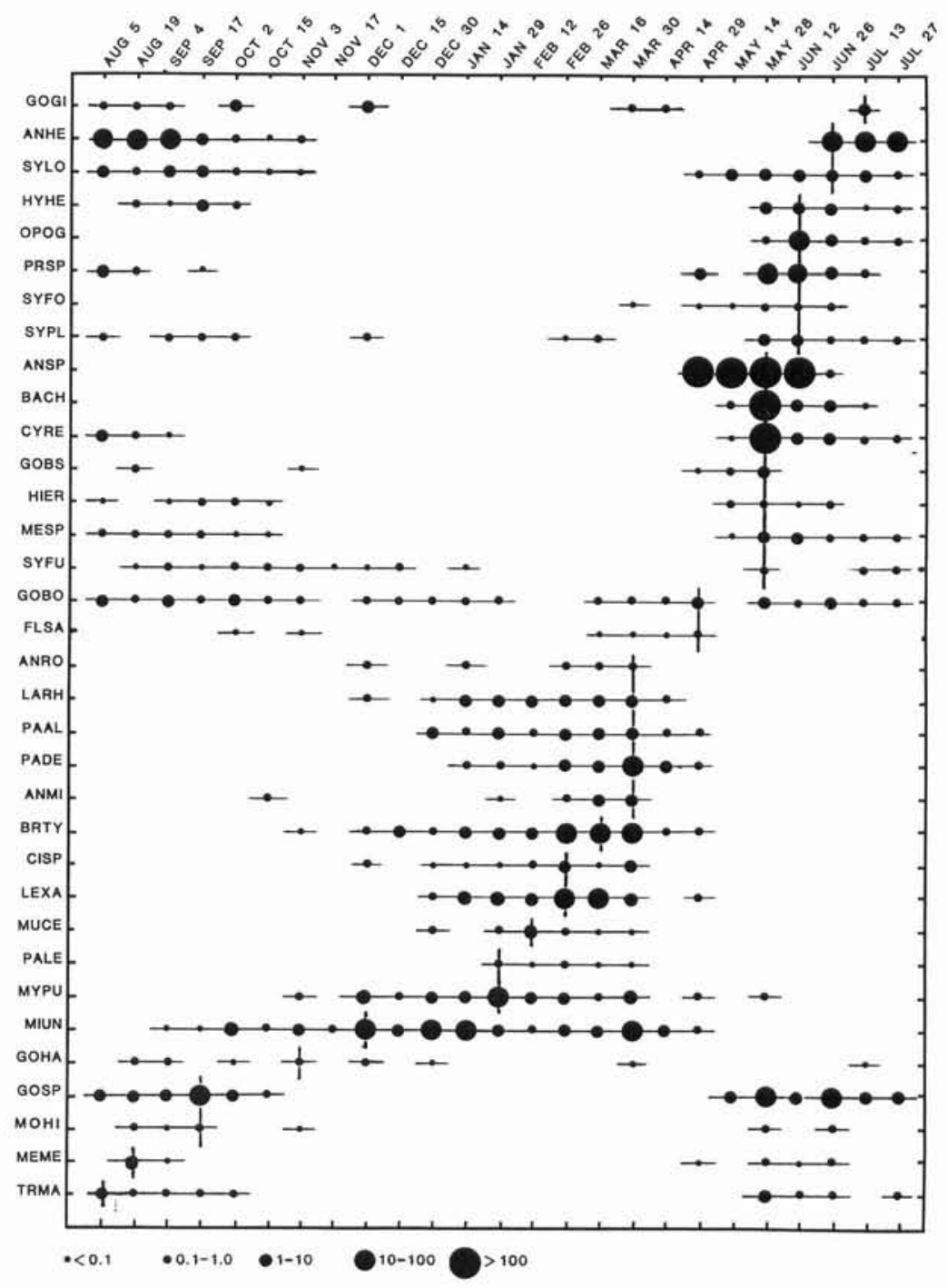




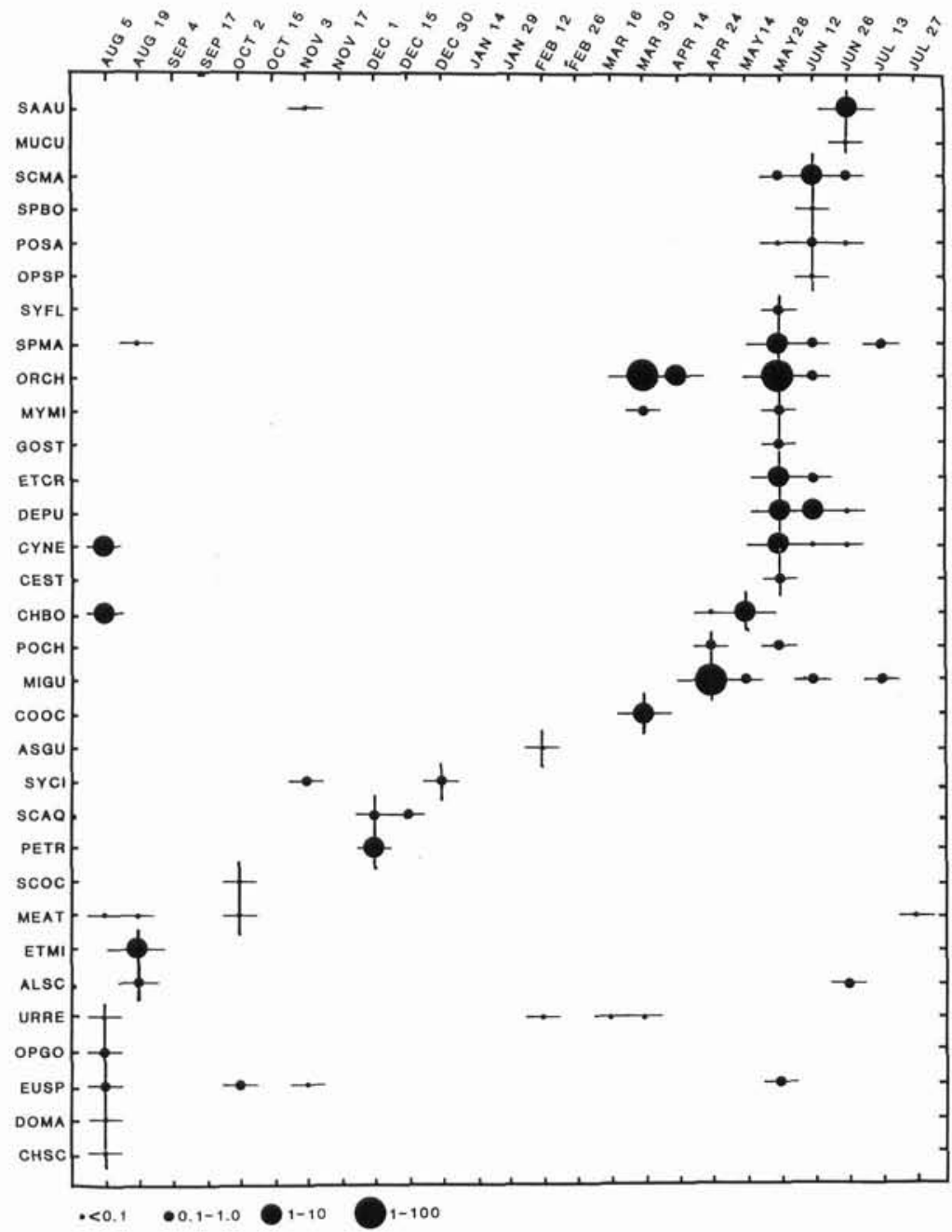

Fig. 4. Date of capture and approximate density of 32 species caught in 4 or less collections with the $0.5 \mathrm{~mm}$ net. Arranged vertically by time of peak density. See Table 1 for species code. Each increase in size of the closed circles represents one order of magnitude increase in relative density
Correspondence analysis successfully resolved species and collection relationships. In 3 dimensions (Fig. 6) the collections formed 4 groups: (1) late spring, with the exception of the August 5 sampling date, (2) summer, (3) winter and early spring, and (4) autumn. The first 3 axes accounted for $66 \%$ of the total chi square deviation. This percentage was similar to that found in other studies of comparable faunal complexity (Gauch 1982). The first axis arranged collections roughly by season, from late spring through summer, autumn, winter, and early spring. The axis was bipolar, with warm water collections (late spring and summer) falling together at one extreme (low scores) and cold water collections (winter and early spring) falling together at the other extreme (high scores). Autumn collections were intermediate. The second axis separated summer collections from winter and spring collections.

Species also were arranged in 3 main groups and one diverse group (Fig. 7). The positions of these species groups was approximately coincident with those of collection groups, and taken together (Figs. 6 \& 7) delineated the seasonal progression of species. Species with low scores on Axes 1 and 2 tended to occur during late spring; those with low scores on Axis 1 and high scores on Axis 2 were associated with the summer period. Within this spring-summer gradient, species with lowest scores on Axis 2 (e.g. Bairdiella chrysoura, Anchoa spp., Cynoscion regalis) tended to peak earlier, and species with highest scores (e.g. Anchoa hepsetus, Menidia menidia, Monacanthus hispidis) occurred later. Intermediate scores reflected the rising and falling abundances of individual species through the spring-summer period. The third group, having high scores on the first axis (e.g. Leiostomus xanthurus, Brevoortia tyrannus, Paralichthys lethostigma), was most common in winter and early spring. Within this group, earlier occurring species (e.g. Micropogonias undulatus) were separated from later species (e.g. $L$. xanthurus) along Axis 3. Species with intermediate scores on both axes (e.g. Gobiosoma ginsburgi, Gobionellus hastatus, Syngnathus fuscus) were characterized by a wide temporal distribution.

Overall, the $0.5 \mathrm{~mm}$ mesh net caught more (Fig. 5) 


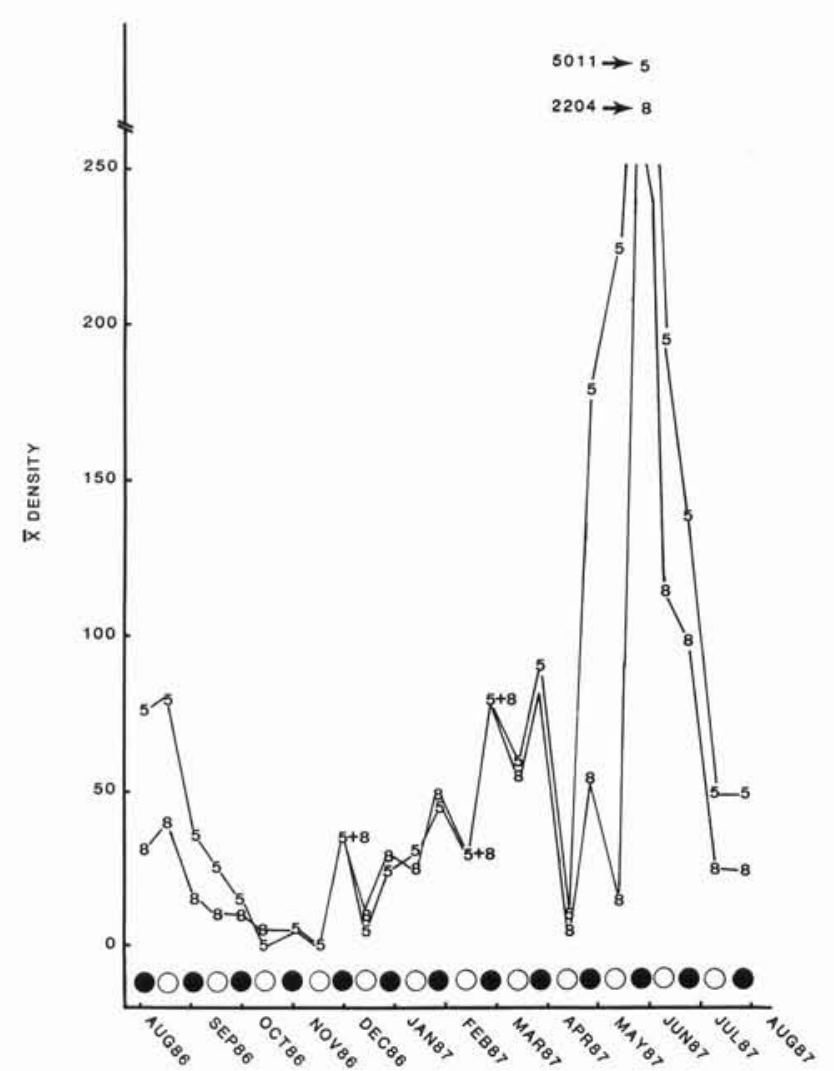

Fig. 5. Mean density (fish per $100 \mathrm{~m}^{3}$ ) by collection for each mesh size. Numeral ' 5 ' $=0.5 \mathrm{~mm}$ mesh net; numeral ' 8 ' $=$ $0.8 \mathrm{~mm}$ mesh net. Collection taken on May 28 was off the vertical scale by an order of magnitude. Moon phase at time of collection: ( $(\circ)$ full moon; $(\bullet)$ new moon. Greater abundances at times of winter new moon due to increased densities of Micropogonias undulatus

and smaller (Fig. 8) larvae than the $0.8 \mathrm{~mm}$ mesh net ( $\mathrm{p}$ $<0.05$; Wilcoxon signed-ranks tests for paired data). Differences in density were not as apparent during colder months (Fig. 3), when fish were generally larger (post-flexion to early juvenile stage) (Table 2). In con- trast, many of the individuals during warm months were smaller (pre-flexion, flexion or early post-flexion stages) and therefore, densities differed markedly between nets. For example, in the late May collections, the $0.8 \mathrm{~mm}$ mesh net caught $56 \%$ less Anchoa sp. larvae (mean length $=6.8 \mathrm{~mm}$ ) than the $0.5 \mathrm{~mm}$ mesh net, where more numerous Anchoa larvae were also smaller (mean length $=5.9 \mathrm{~mm}$ ). Of the 61 species caught in both nets, the average size of larvae collected with $0.5 \mathrm{~mm}$ mesh was smaller for 40 species, but larger for 21 species (Fig. 8). Of the 21 species that did not fit the expected pattern, i.e. on or above the nodifference' line in Fig. 8, only 4 species had average lengths less than $8 \mathrm{~mm}$.

Total densities of ichthyoplankton were significantly greater in almost every new moon collection than in the preceding full moon collection during the mid-October through April period (Fig. 5). However, this was due to Micropogonias undulatus, which were taken throughout this time period and had consistently greater mean densities during new moons. Densities of other common species, such as Brevoortia tyrannus, Gobionellus boleosoma, Lagodon rhomboides, Leiostomus xanthurus, and Menticirrhus spp., were not correlated with moon phase. The greatest densities of Paralichthys albigutta and $P$. dentatus were taken during the new moon of late March. For Gobiosoma hastatus, 6 out of 8 collections in which they occurred were taken during new moon spring tides. Similarly, Myrophis punctatus were collected in 8 new moon collections, but only 4 full moon collections. An obvious conclusion might be that net avoidance was greater in full moonlight; however, most of the sampling tows occurred between nightfall and moon rise during the winter and thus sea surface illumination was not a direct factor.

During late fall and early winter, catches may have been related to wind speed. In 4 months, November to February, total catches were greater when wind speed
Fig. 6. Separation of the 25 collections by season using correspondence analysis on $0.5 \mathrm{~mm}$ mesh catches. Dimensional axes ('DIM') are arbitrary

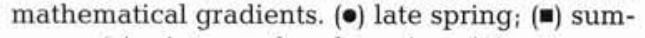
mer; $(\circ)$ winter and early spring; $(\diamond)$ autumn

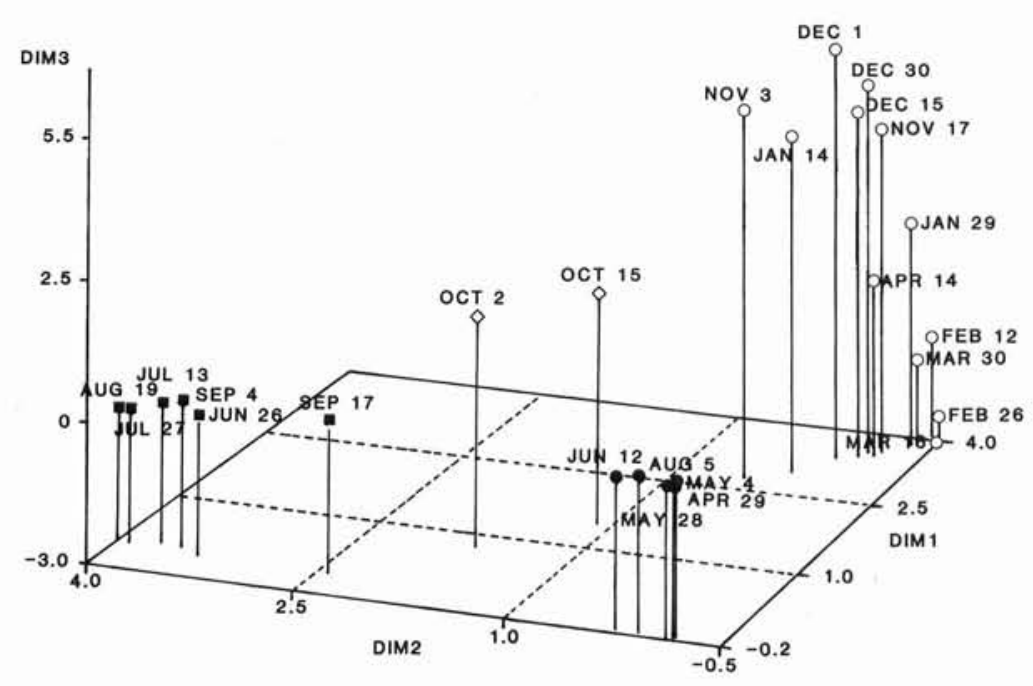




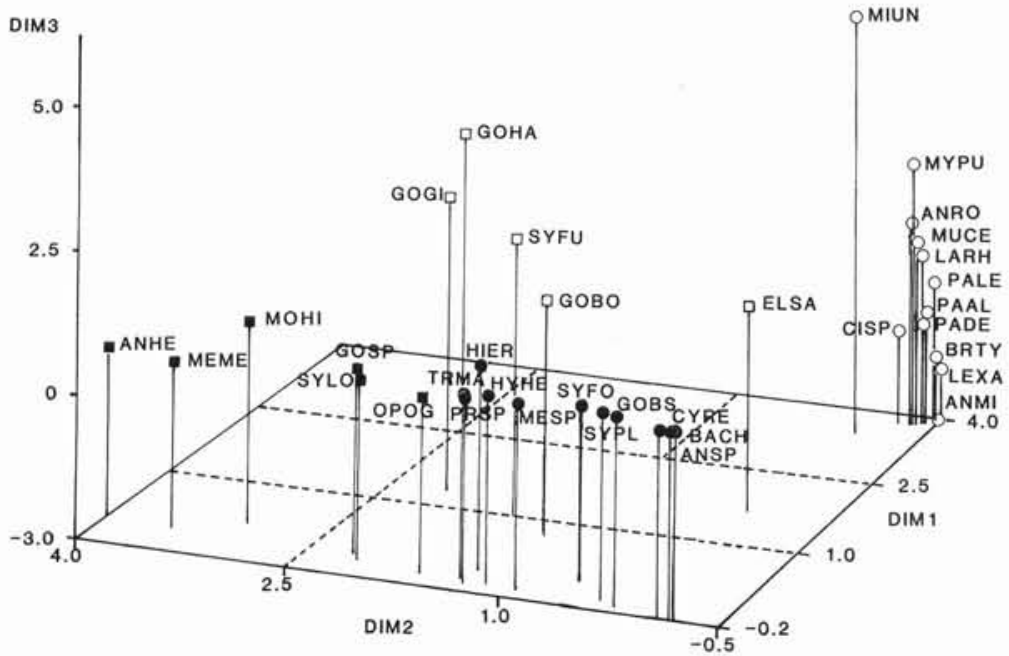

was higher (Figs. $1 \&$ 5). In 3 of those months, conditions of no wind and full moon coincided.

Variability in total catch among hauls within collections was high. The average coefficient of variation was $48.8 \%$ (range 2.1 to $124.1 \%$ ) for the $0.5 \mathrm{~mm}$ mesh net and $54.1 \%$ (range 16.6 to $122.3 \%$ ) for the $0.8 \mathrm{~mm}$ mesh net. No seasonal trends were evident. The effect of within-collection variance on the numer of replicates required to detect a given difference between 2 collection means was calculated. Based on the observed average coefficient of variation, 5 replicates per collection are necessary to ensure a $75 \%$ probability of detecting (at the $5 \%$ significance level) a factor of 2 difference between any 2 collection means (Fig. 9).

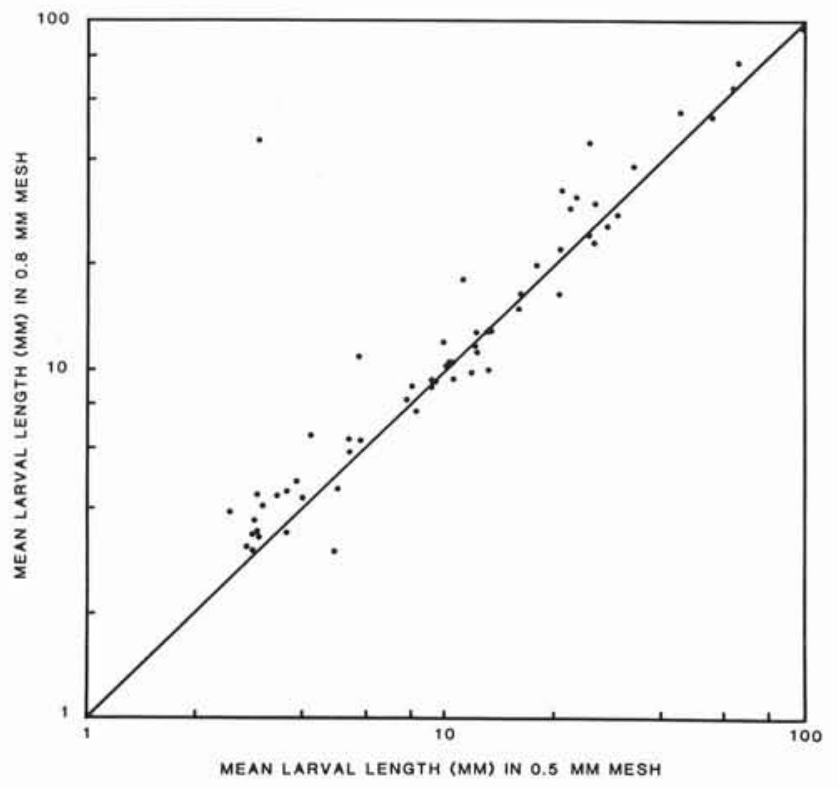

Fig. 8. Fish lengths, by species, compared by mesh size. Points above the 'no difference' line represent species whose mean lengths are smaller in the $0.5 \mathrm{~mm}$ mesh, as expected
Fig. 7. Separation of species into seasonal groups using correspondence analysis on $0.5 \mathrm{~mm}$ mesh catches. Axes ('DIM') are arbitrary mathematical gradients using species occurring in 5 or more collections as shown in Fig. 3. (•) Late spring; (घ) summer; (○) winter/early spring; ( $\square$ ) wide temporal distribution

\section{DISCUSSION}

The cold-water assemblage of species (November to April) was similar in principal species composition to that reported by Warlen \& Burke (1990). These authors sampled with a bongo net within $1 \mathrm{~km}$ of our station during the previous season (1985-1986) and collected 22 fish species. We collected 29 species with the pushnet during this period a year later. They collected 4 species that we did not: Albula vulpes, Dormitator maculatus, Gobionellus shufeldti, and Paralichthys squamilentus. We collected 8 species that they did not: Conger oceanicus, Peprilus triacanthus, Gobiosoma ginsburgi, Mycteroperca microlepis, Astroscopus guttatus, Syngnathus fuscus, Symphurus plagiusa, and Scopthalmus aquosus. We found pigfish Orthopristis chrysoptera occurring in 2 peaks (late March and late May/early June), while Warlen \& Burke (1990) found that pigfish only recruited for 1 mo (early April). Furthermore, they caught Atlantic croaker $(>8 \mathrm{~mm}$ mean standard length) from mid-November, when their sampling began, and reported a $6 \mathrm{wk}$ period around January of low recruitment. We collected $5 \mathrm{~mm}$ Atlantic croaker as early as September 4 and noted continuous recruitment of this species through to April 29. Lewis \& Judy (1983) also caught Atlantic croaker in the Newport River estuary (adjacent to our inlet station) as early as September, but did not catch this species later than March in the upper water column of the estuary.

Several incompletely identifiable species groups (codes ending in 'spp.' in Table 1) make the interpretation of species assemblages (Fig. 7) difficult, particularly regarding the Anchoa spp. and Gobiosoma spp. larvae. Anchovy smaller than about $7 \mathrm{~mm}$ had not developed fin ray counts necessary to separate A. hepsetus from $A$. mitchilli and other possible anchovy species occasionally found off the North Carolina coast (e.g. Engraulis eurystole) (= species code ANSP). 
Table 2. Mean length $(\mathrm{mm})$ of species caught in $0.5 \mathrm{~mm}$ mesh net by month

\begin{tabular}{|c|c|c|c|c|c|c|c|c|c|c|c|c|}
\hline \multirow[b]{2}{*}{ Species (66) by family ( 34 ) } & \multirow[b]{2}{*}{ Aug } & \multirow[b]{2}{*}{ Sep } & \multirow[b]{2}{*}{ Oct } & \multirow[b]{2}{*}{ Nov } & \multirow[b]{2}{*}{ Dec } & \multicolumn{2}{|c|}{ Month } & \multirow[b]{2}{*}{ Mar } & \multirow[b]{2}{*}{ Apr } & \multirow[b]{2}{*}{ May } & \multirow[b]{2}{*}{ Jun } & \multirow[b]{2}{*}{ Jul } \\
\hline & & & & & & Jan & Feb & & & & & \\
\hline Elopidae & & & & & & & & & & & & \\
\hline Elops saurus & & & 34.0 & 32.0 & & & & 35.0 & 33.0 & & & \\
\hline Megalops atlanticus & 23.5 & & 24.0 & & & & & & & & & 25.0 \\
\hline Anguillidae & & & & & & & & & & & & \\
\hline Anguilla rostrata & & & & & 51.0 & 52.5 & 52.5 & 59.2 & & & & \\
\hline Congridae & & & & & & & & & & & & \\
\hline Conger oceanicus & & & & & & & & 103.0 & & & & \\
\hline Ophichthidae & & & & & & & & & & & & \\
\hline Ophicthus gomesi & 65.2 & & & & & & & & & & & \\
\hline Myrophis punctatus & & & & 60.2 & 62.4 & 63.8 & 63.7 & 69.2 & 46.4 & 45.0 & & \\
\hline Clupeidae & & & & & & & & & & & & \\
\hline Brevoortia tyrannus & & & & 16.0 & 22.3 & 23.8 & 27.1 & 27.6 & 24.0 & & & \\
\hline Opisthonema oglinum & & & & & & & & & & 21.0 & 11.4 & 15.4 \\
\hline Sardinella aurita & & & & 32.0 & & & & & & & 27.8 & \\
\hline Engraulidae & & & & & & & & & & & & \\
\hline Anchoa hepsetus & 7.4 & 10.5 & 13.5 & 33.3 & & & & & & & 13.9 & 6.8 \\
\hline A. mitchilli & & & 20.0 & & & 29.0 & 39.0 & 33.0 & & & & \\
\hline Anchoa sp. & & & & & & & & & 5.9 & 5.3 & 6.8 & \\
\hline Synodontidae & & & & & & & & & & & & \\
\hline Synodus foetens & & & & & & & & 26.0 & 33.0 & 31.7 & 16.8 & \\
\hline Gobiesocidae & & & & & & & & & & & & \\
\hline Gobiesox strumosus & & & & & & & & & & 4.0 & & \\
\hline Gadidae & & & & & & & & & & & & \\
\hline Urophycis regia & 2.5 & & & & & & 31.0 & 38.0 & & & & \\
\hline Ophidiidae & & & & & & & & & & & & \\
\hline Ophidion sp. & & & & & & & & & & & 17.0 & \\
\hline Atherinidae & & & & & & & & & & & & \\
\hline Menidia menidia & 3.3 & 3.0 & & & & & & & 8.0 & 5.0 & 6.0 & \\
\hline Syngnathidae & & & & & & & & & & & & \\
\hline Hippocampus erectus & 18.0 & 8.0 & 14.4 & & & & & & & 9.0 & 9.5 & \\
\hline Syngnathus floridae & & & & & & & & & & 20.6 & & \\
\hline S. fuscus & 60.0 & 21.5 & 13.2 & 24.2 & 40.0 & 75.0 & & & & 31.4 & & 22.0 \\
\hline S. louisianae & 33.9 & 15.4 & 41.5 & 19.0 & & & & & 31.1 & 20.5 & 30.0 & 33.7 \\
\hline Serranidae & & & & & & & & & & & & \\
\hline Centropristis striata & & & & & & & & & & 4.0 & & \\
\hline Mycteroperca microlepis & & & & & & & & 16.5 & & 15.5 & & \\
\hline Pomatomidae & & & & & & & & & & & & \\
\hline Pomatomus saltatrix & & & & & & & & & & 31.0 & 20.5 & \\
\hline Carangidae & & & & & & & & & & & & \\
\hline Decapterus punctatus & & & & & & & & & & 2.8 & 2.8 & \\
\hline Gerreidae & & & & & & & & & & & & \\
\hline Eucinostomus sp. & 10.4 & & 10.5 & & & & & & & 11.0 & & \\
\hline Haemulidae & & & & & & & & & & & & \\
\hline Orthopristis chrysoptera & & & & & & & & 11.3 & 8.6 & 4.9 & 5.1 & \\
\hline Sparidae & & & & & & & & & & & & \\
\hline Lagodon rhomboides & & & & & 11.4 & 12.7 & 12.9 & 14.0 & 16.1 & & & \\
\hline Sciaenidae & & & & & & & & & & & & \\
\hline Bairdiella chrysoura & & & & & & & & & & 2.4 & 3.2 & \\
\hline Cynoscion nebulosus & 3.1 & & & & & & & & & 2.2 & 2.5 & 3.0 \\
\hline C. regalis & 3.1 & 4.0 & & & & & & & & 2.7 & 3.0 & 3.5 \\
\hline Leiostomus xanthurus & & & & & 11.7 & 13.8 & 16.8 & 18.9 & 12.5 & & & \\
\hline Menticirrhus sp. & 2.8 & 2.7 & 4.0 & & & & & & & 3.7 & 2.6 & 2.8 \\
\hline Micropogonias undulatus & & 5.0 & 6.5 & 7.5 & 10.3 & 10.4 & 11.3 & 11.2 & 8.6 & & & \\
\hline Pogonias chromis & & & & & & & & & 3.7 & 4.0 & & \\
\hline Sciaenops ocellatus & & & 5.0 & & & & & & & & & \\
\hline Mugilidae & & & & & & & & & & & & \\
\hline Mugil cephalus & & & & & 23.4 & 18.4 & 22.0 & 23.7 & & & & \\
\hline M. curema & & & & & & & & & & & 26.0 & \\
\hline Sphyraenidae & & & & & & & & & & & & \\
\hline Sphyraena borealis & & & & & & & & & & & 3.0 & \\
\hline
\end{tabular}


Table 2 (continued)

\begin{tabular}{|c|c|c|c|c|c|c|c|c|c|c|c|c|}
\hline \multirow[b]{2}{*}{ Species (66) by family (34) } & \multirow[b]{2}{*}{ Aug } & \multirow[b]{2}{*}{ Sep } & \multirow[b]{2}{*}{ Oct } & \multirow[b]{2}{*}{ Nov } & \multirow[b]{2}{*}{ Dec } & \multicolumn{2}{|c|}{ Month } & \multirow[b]{2}{*}{ Mar } & \multirow[b]{2}{*}{ Apr } & \multirow[b]{2}{*}{ May } & \multirow[b]{2}{*}{ Jun } & \multirow[b]{2}{*}{ Jul } \\
\hline & & & & & & Jan & Feb & & & & & \\
\hline \multicolumn{13}{|l|}{ Uranoscopidae } \\
\hline Astroscopus guttatus & & & & & & & 18.0 & & & & & \\
\hline \multicolumn{13}{|l|}{ Blennidae } \\
\hline Hypsoblennius hentzi & 2.3 & 2.5 & 2.0 & & & & & & & 3.6 & 3.0 & 3.7 \\
\hline Chasmodes bosguianus & 3.4 & & & & & & & & 3.0 & 2.6 & & \\
\hline \multicolumn{13}{|l|}{ Eleotridae } \\
\hline Dormitator maculatus & 8.0 & & & & & & & & & & & \\
\hline \multicolumn{13}{|l|}{ Gobiidae } \\
\hline Gobionellus boleosoma & 8.1 & 8.3 & 8.3 & 9.3 & 10.1 & 9.5 & & 10.2 & 10.4 & 8.8 & 8.8 & 8.6 \\
\hline G. hastatus & 14.3 & 9.5 & 10.0 & 11.2 & 14.0 & & & 17.0 & 9.0 & & & 9.0 \\
\hline Gobiosoma bosci & 4.7 & & 5.2 & & & & & & 7.0 & 7.0 & & \\
\hline G. ginsburgi & 8.9 & 8.4 & 8.0 & & 9.8 & & & & 15.0 & & & 9.2 \\
\hline Gobiosoma sp. & 3.4 & 3.8 & 5.4 & & & & & & & 3.3 & 3.6 & 4.2 \\
\hline Microgobius gulosus & & & & & & & & & 6.1 & 6.0 & 4.1 & 5.0 \\
\hline \multicolumn{13}{|l|}{ Scombridae } \\
\hline Scomberomorus maculatus & & & & & & & & & & 3.5 & 3.7 & \\
\hline \multicolumn{13}{|l|}{ Stromateidae } \\
\hline Peprilus triacanthus & & & & & 18.0 & & & & & & & \\
\hline \multicolumn{13}{|l|}{ Triglidae } \\
\hline Prionotus sp. & 3.1 & 3.0 & & & & & & & 5.0 & 4.2 & 3.1 & 4.1 \\
\hline \multicolumn{13}{|l|}{ Bothidae } \\
\hline Citharichthys sp. & & & & & 9.7 & 9.0 & 10.7 & 9.9 & & & & \\
\hline Etropus crossotus & & & & & & & & & & 3.1 & 4.0 & \\
\hline E. microstomus & 8.2 & & & & & & & & & & & \\
\hline Paralichthys albigutta & & & & & 9.1 & 9.9 & 10.3 & 10.5 & 9.0 & & & \\
\hline P. dentatus & & & & & & 12.0 & 13.8 & 13.2 & 12.6 & & & \\
\hline P. lethostigma & & & & & & 11.5 & 11.5 & 12.7 & & & & \\
\hline Scopthalmus aguosus & & & & & 5.8 & & & & & & & \\
\hline Soleidae & & & & & & & & & & & & \\
\hline Trinectes maculatus & 3.0 & 3.2 & 3.0 & & & & & & & 2.6 & 2.8 & 2.5 \\
\hline \multicolumn{13}{|l|}{ Cynoglossidae } \\
\hline Symphurus civitatus & & & & 11.5 & 13.0 & & & & & & & \\
\hline S. plagiusa & 8.8 & 6.8 & 10.0 & & 12.5 & & 11.0 & 10.0 & & 2.6 & 2.8 & 2.5 \\
\hline \multicolumn{13}{|l|}{ Balistidae } \\
\hline Aluterus schoepfi & & 18.8 & & & & & & & & & 4.4 & \\
\hline Monacanthus hispidus & 7.0 & 8.0 & & 27.0 & & & & & & 11.0 & 6.0 & \\
\hline Tetradontidae & & & & & & & & & & & & \\
\hline Sphoeroides maculatus & 4.0 & & & & & & & & & 3.5 & 3.7 & 3.0 \\
\hline Diodontidae & & & & & & & & & & & & \\
\hline Chilomycterus schopefi & 11.0 & & & & & & & & & & & \\
\hline
\end{tabular}

Gobies (GOSP) less than about $7 \mathrm{~mm}$ may have been G. bosci, G. ginsburgi, Microgobius gulosus, or $M$. thalassinus. Three species of Menticirrhus spawn along the North Carolina coast, but their larvae could not be identified to species for reasons discussed by Powles \& Stender (1978). Ruple (1984) had similar identification problems with Menticirrhus spp., as well as small anchovy, gobies, and Cynoscion spp. Several possibile species of Prionotus, 2 possible species of Eucinostomus and several undeveloped bothids also could not be identified to species reliably.

The apparent lunar periodicity of new vs full moon we observed in the densities of the cold-water community could not be corroborated with examples from the literature. Robertson et al. (1987) reported settlement peaks of damselfish larvae Stegastes paritus $3 \mathrm{~d}$ before new moon. Yellowfin bream Acanthopagrus australis larvae entered the estuary at night on full moon tides, but Pollock et al. (1983) could not resolve whether the full moon was a cue for these larvae to enter the estuary or if observed peaks were due to spawning. Previous studies on the fishes around Beaufort have not related observed densities to lunar periodicity. However, monthly density peaks of Atlantic croaker from November to April (except for the low recruitment period in January) as reported by Warlen \& Burke (1990) were coincident with times of new moon; they did not comment on this apparent relationship. Their data for other principal species did not correlate with lunar phase.

Considerable variability between hauls within collections suggests that ichthyoplankton distribution and 


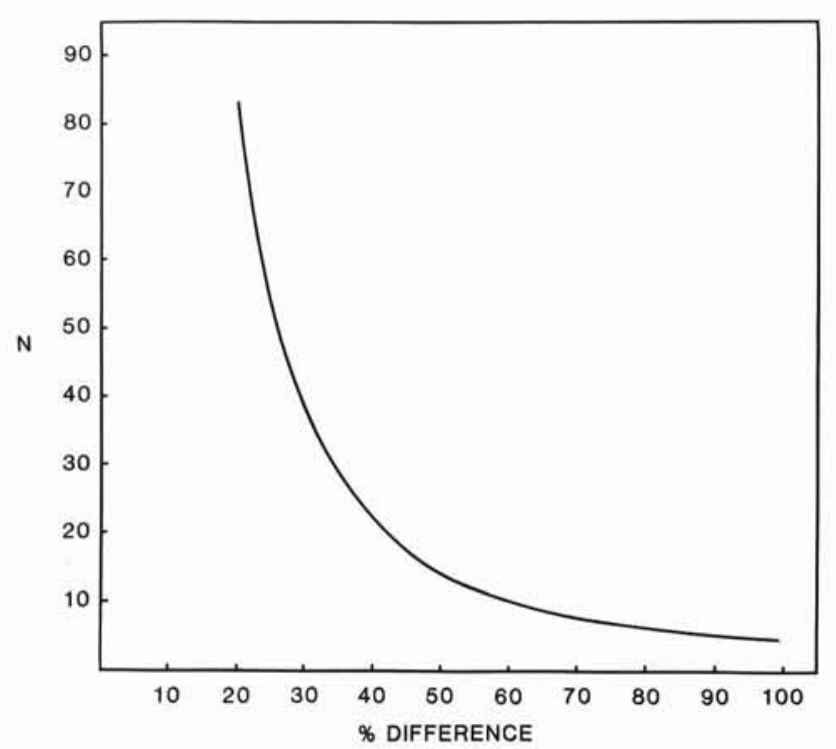

Fig. 9. Number of replicate hauls (N) needed to be $75 \%$ certain of detecting a given difference between 2 population means at the $5 \%$ level of significance. Based on total densities from $0.5 \mathrm{~mm}$ mesh net with a mean coefficient of variation $=$ $48.83 \%$

abundance studies in highly dynamic flux locations, such as inlets, should not rely on 1 or 2 short-duration tows for abundance measurements. Time and budget limits usually prevent large numbers of replicate hauls. Even with 6 consecutive hauls made at the same fixed station over a time of $2 \mathrm{~h}$, high variability between hauls was observed. Determining the number of replicate hauls to achieve acceptable precisions in a particular environment can best be determined by preliminary gear tests, but we found that less than 5 replicate hauls was not satisfactory in the inlet sampled.

Ichthyofauna collected in this study was compared to the nekton community found to invade a nearby saltmarsh, primarily as juveniles (Hettler 1989). Of the 35 species of fish found in the marsh habitat, 25 were also members of the ichthyoplankton community. Leiostomus xanthurus, caught in densities up to 65 per $100 \mathrm{~m}^{3}$ with the pushnet in late February, were noted to invade the marsh in large numbers in mid-March of the same year. The average number of $L$. xanthurus in the intertidal marsh habitat in March was 49 per lineal meter of Spartina alterniflora marsh edging a tidal creek. The Cyprinodontidae (killifishes), which were significant components of the marsh community, were never found in the ichthyoplankton samples. Engraulidae, the dominant family in the ichthyoplankton, were found in low abundance in the marsh. Brevoortia tyrannus and Micropogonias undulatus, also prominent members of the cold-water larval assemblage, were never found in the marsh habitat. $B$. tyrannus juveniles are known to prefer oligohaline tidal creeks and $M$. undulatus juveniles are found mainly in deeper, openwater mesohaline habitats. It is not surprising that $60 \%$ of the species collected in the pushnet were not linked to the adjacent saltmarsh habitat, given the availability of other complex habitats (bare substrate bottoms, seagrass beds, oyster reefs, or tidal creeks), but most of these habitats in North Carolina have not been adequately sampled to determine their use by early juvenile fishes.

Densities reported in our paper may not represent densities throughout the water column, even though the transect site was a high-energy, well-mixed, relatively shallow inlet. The main disadvantage of this pushnet is that only the upper part of the water column can be sampled. A study (by W.F.H.) is in progress that will compare flood vs ebb tide and near-surface vs near-bottom catches of ichthyofauna at the same station occupied during the present study. Weinstein et al. (1980) found that Paralichthys spp. and Leiostomus xanthurus larvae in the Cape Fear River, North Carolina, tended to congregate at the surface at night; Micropogonias undulatus did not. Thayer et al. (1983) noted unequal distribution of these and other species in surface and bottom (5 to $10 \mathrm{~m}$ depth) tows outside Beaufort Inlet. In contrast, Warlen \& Burke (1990) reported no within-species differences between neuston and oblique (mid-water) bongo tows inside Beaufort Inlet.

Mesh size made a difference in total catches and size distribution of larval fishes. Smaller mesh reduces extrusion of larvae through the mesh and thus retains more small fish, but this becomes a disadvantage when net pores clog with suspended debris, reducing water flow through the net and increasing the pressure wave in front of the net, which may help larvae avoid capture. Thus, net mesh size selection is important and should be determined by the size of the target species.

In summary, this study provides a database on the species, numbers, and sizes of larval/early juvenile fishes in a North Caroline inlet throughout an entire year. Species were classified into 3 main temporal assemblages: winter and early spring, late spring, and summer. All species collected during winter were advanced post-flexion larvae or juveniles, while many of the spring/summer species were pre-flexion and flexion larvae. Peak larval densities occurred in late spring, whereas the nadir was in November. Variation in densities of the total catch of the winter/early spring group, as well as for a few species, especially Micropogonias undulatus, was related to lunar phase, but most species were not. Anchovy dominated the nonwinter catches. Variability in observed total fish densities between hauls within collections was high. About one-third of the species found in the collections later utilized nearby marshes as a nursery habitat, but 
the subsequent preferred habitats of many other species is unclear. A better understanding of the movements of transforming larval and juvenile fish in North Carolina estuaries following their passage through inlets will depend on the development of techniques to measure the distribution and abundance of these later life history stages in various shallow-water habitats.

Acknowledgements. We thank the many people who assisted in field collections, especially John Burke, Don Jacobsen, and Lisa Hettler. Sheryan Epperly, Jeff Govoni, and David Peters reviewed an early version of the manuscript. Three anonymous reviewers contributed to the final version of the manuscript.

\section{LITERATURE CITED}

CP \& L (1989). Brunswick Steam Electric Plant. 1988 biological monitoring report. Carolina Power \& Light Company, New Hill, North Carolina

Gauch, H. G., Jr (1982). Noise reduction by eigenvector ordinations. Ecology 63: 1643-1649

Gauch, H. G., Whittaker, R. H., Singer, S. B. (1981). A comparative study of nonmetric ordinations. J. Ecol. 69: 135-152

Greenacre, M. J. (1984). Theory and applications of correspondence analysis. Academic Press, New York

Hettler, W. F., Jr (1989). Nekton use of regularly-flooded saltmarsh cordgrass habitat in North Carolina, USA. Mar. Ecol. Prog. Ser. 56: 111-118

Hildebrand, S. F., Cable, L. E. (1930). Development and life history of fourteen teleostean fishes at Beaufort, N.C. Bull. U.S. Bur. Fish. 46: 383-488

Hildebrand, S. F., Cable, L. E. (1938). Further notes on the development and life history of some teleosts at Beaufort, N.C. Bull. U.S. Bur. Fish. 48: 505-642

Hodson, R. G., Bennett, C. R., Monroe, R. J. (1981). Ichthyoplankton samplers for simultaneous replicate samples at surface and bottom. Estuaries 4: 176-184

Judy, M. H. (1982). Catch composition, seasonality, and distribution of ichthyoplankton from R/V Onslow Bay monthly cruises in Onslow Bay and Newport River estuary, North Carolina, 1972-1974. NOAA Tech. Memo. NMFSSEFC 46

Lewis, R. M., Judy, M. H. (1983). The occurrence of spot, Leiostomus xanthurus, and Atlantic croaker, Micropogonias undulatus, larvae in Onslow Bay and Newport River estuary, North Carolina. Fish. Bull. U.S. 81: 405-412

This article was presented by Dr K. Sherman, Narragansett, Rhode Island, USA
Lewis, R. M., Mann, W. C. (1971). Occurrence and abundance of larval Atlantic menhaden, Brevoortia tyrannus, at two North Carolina inlets with notes on associated species. Trans. Am. Fish. Soc. 100: 296-301

Lewis, R. M., Wilkens, E. P. H. (1971). Abundance of Atlantic menhaden larvae and associated species during a diel collection at Beaufort, North Carolina. Chesapeake Sci. 12: 185-187

Olney, J. E., Boehlert, G. W. (1988). Nearshore ichthyoplankton associated with seagrass beds in the lower Chesapeake Bay. Mar. Ecol. Prog. Ser. 45: 33-43

Pielou, E. C. (1984). The interpretation of ecological data. Wiley, New York

Pollock, B. R., Weng, H., Morton, R. M. (1983). The seasonal occurrence of post larval stages of yellowfin bream Acanthopagrus australis and some factors affecting their movement into an estuary. J. Fish. Biol. 22: 409-416

Powles, H., Stender, B. W. (1978). Taxonomic data on the early life history stages of Sciaenidae of the South Atlantic Bight of the United States. S.C. Mar. Resour. Center Tech. Rep. 31: $1-64$

Robertson, D. R., Green, D. G., Victor, B. C. (1987). Relations in the lunar periodicities of larval production and settlement by a Caribbean reef fish. Bull. mar. Sci. 41: 641

Ruple, D. L. (1984). Occurrence of larval fishes in the surf zone of a northern Gulf of Mexico barrier island. Estuar. coast. Shelf Sci. 18: 191-208

Tagatz, M. E., Dudley, D. L. (1961). Seasonal occurrence of marine fishes in four shore habitats near Beaufort, N. C., 1957-1960. U.S. Fish Wildl. Ser. SSR-Fish. No. 390

Thayer, G. W., Colby, D. R., Kjelson, M. A., Weinstein, M. P. (1983). Estimates of larval-fish abundance: diurnal variation and influences of sampling gear and towing speed. Trans. Am. Fish. Soc. 112: 272-279

Thayer, G. W., Hoss, D. E., Kjelson, M. A., Hettler, W. F., LaCroix, M. W. (1974). Biomass of zooplankton in the Newport River estuary and the influence of postlarval fishes. Chesapeake Sci. 15: 9-16

Warlen, S. M. (1982). Age and growth of larvae and spawning time of Atlantic croaker in North Carolina. Proc. Ann. Conf. Southeast. Ass. Fish Wildl. Agencies 34: 204-214

Warlen, S. M., Burke, J. S. (1990). Immigration of larvae of fall/ winter spawning marine fishes into a North Carolina estuary. Estuaries 13 (4): in press

Warlen, S. M., Chester, A. J. (1985). Age, growth, and distribution of larval spot, Leiostomus xanthurus, off North Carolina. Fish. Bull. U.S. 83: 587-599

Weinstein, M. P., Weiss, S. L., Hodson, R. G., Gerry, L. R. (1980). Retention of three taxa of postlarval fishes in an intensively flushed tidal estuary, Cape Fear River, North Carolina. Fish. Bull. U.S. 78: 419-436

Manuscript first received: April 6, 1990

Revised version accepted August 31, 1990 